\title{
Research on the Construction of Urban Community Health Service Chain Model
}

\author{
Li Wang \\ School of Public Affairs and Administration \\ University of Electronic Science and Technology of China \\ Chengdu, China
}

\begin{abstract}
According to the current status of urban community health service, based on the collection of domestic community health service related literature, it uses the grounded theory to conduct qualitative analysis, builds the urban community health service chain model according to the service chain theory, and sorts out the community health service content as well as the corresponding organizations that provide the service.
\end{abstract}

Keywords-urban community; service chain; grounded theory; community health service

\section{INTRODUCTION}

Community health service is a branch of public service and a key link in urban community and health care development. The World Health Organization (WHO) has pointed out that grassroots community health services can solve more than $80 \%$ of urban residents' health problems.

In addition, with the improvement of people's living standards, the scientific concept of health has gradually been recognized and accepted by the public. The public's demand for medical care has been upgraded from the treatment of existing diseases to the maintenance of self-physical health and disease prevention, which caused residents' demand for medical and health service dramatically increased, and community health services are facing enormous challenges.

In 2015, the "Community Health Service Improvement Project" initiated by the country has formulated the goal of "significant improvement of the environment of community health service institutions, gradual improvement of service functions and substantial improvement of service quality by 2020 ", and proposed to adhere to the principles of "demandoriented and perfect services", "people-oriented, promoting health", "continuous improvement, quality improvement" and "innovation practice, perfecting the system", and improving the development requirements of "service capability", "quality of service", "management level" and "guarantee conditions" [1].

\section{The CURRENT SituAtion OF RESEARCH}

The existing research literature on community health service demands in China is mainly divided into two categories, one is the demand survey and analysis for the staff

\author{
Liwen Liang \\ School of Public Affairs and Administration \\ University of Electronic Science and Technology of China \\ Chengdu, China
}

of community health service institutions, and the other is the demand survey and analysis conducted for the residents.

In the staff-oriented demands study, Liu Hongyu et al (2017) used the Health Manpower Needs Analysis Tool (WISN) developed by the World Health Organization to sample five community health service agencies in Yinchuan and Guyuan, analyze the demands of community health service staff [2]. Yang Xuesong et al (2016) used a cluster random sampling method to sample and then conducted a questionnaire survey to analyze the training demands of general practitioners and administrators of infectious diseases institutions in the eight districts of Beijing City [3]. Zheng Chanjiao et al. (2015) used questionnaires to investigate and analyze the demands of health technicians in Guangdong Community Health Service Centers on service capacity training [4]. Wang Haiyin et al. (2013) conducted a questionnaire survey of clinical medical staff in 44 community health service centers in 4 districts of Shanghai to explore their demand for health-appropriate technologies [5].

In the study of residents' demands, Zhang Jianfeng et al (2010) conducted a household survey of empty nest aged 60 and above in Hefei city through a questionnaire survey, and analyzed the factors affecting the demand for community health services by empty nest [6]. Chen Ying (2016) analyzed the demands and characteristics of medical care for the elderly in Hong Kong, and put forward opinions on the demand analysis of medical services for the elderly in China [7]. Ma Guofang et al. (2017) conducted a sample questionnaire survey and interviews with migrants aged 16 to 60 in Urumqi to analyze the demands of the floating population for community health service projects [8].

In summary, in the field of community health service demand in China, literature research almost stops at the status quo investigation, the method is single, the service content is incomplete, and the service organization is missing, which makes the community health service lacks a viable development path on the aspects of meeting the diversified, multi-level and multi-layer demands of residents. There is an urgent need to clarify the content of community health services.

\section{SERVICE CHAIN THEORY}

Service Chain (SC) refers to a supply chain formed by a certain supporting process for an organization that has a 
specific service capability to meet the needs of the service object.

The service chain is composed of "nodes", that is, enterprises and institutions that provide the required services for the service objects. These "nodes" form a "chain" through certain forms, and provide a full range of services for the service objects through the "service chain" in order to realize its own interests. If the corresponding service "node" has not yet been generated, the "node" will be quickly generated to meet the demand under market regulation, and the new "node" that meets the "chain" requirements can be quickly integrated into the entire service chain. [9].

This paper intends to build an urban community health service chain model based on the service chain theory, sort out the health service demands of urban communities and the supply institutions of service demand, and provide decision support for the improvement of the quality of health services in urban communities.

\section{QUALITATIVE ANALYSIS OF URBAN COMMUNITY HEALTH SERVICE DEMANDS}

\section{A. Analysis Steps}

According to the operation procedure of the grounded theory, the analysis steps are as follows: The first step is to collect and organize the data. The second step, first-level coding to the data (also known as open coding), that is, the researcher reads the collected texts word by word in a free and open manner, analyzes the attributes displayed by the documents themselves, and then downgrade it step by step based on the criteria of grounded theory. The third step, the second-level coding (also called the main axis coding) is a relatively open coding, thereby discovering and establishing the relationship between the various functional categories, thus showing the links between the various parts of the document. The fourth step, the three-level coding (also known as selective coding), is that the researcher systematically analyzes the existing generics, and then promotes the concept again, and finally selects the "core generics" and builds the model. The specific analysis steps are shown in "Fig. 1".

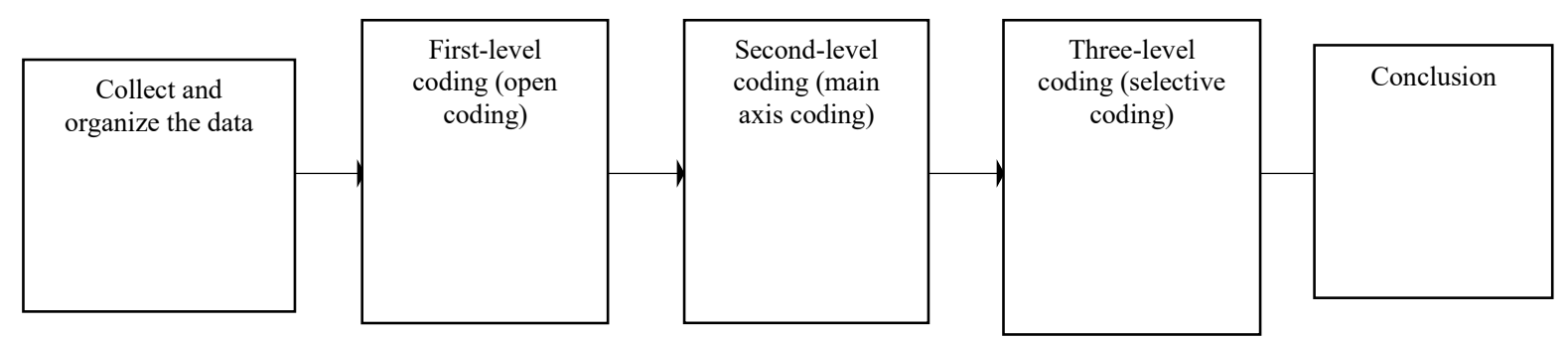

Fig. 1. Qualitative analysis steps of urban community health service demands.

\section{B. Data Source and Collection}

The data sources of this paper include China National Knowledge Infrastructure (CNKI), Wanfang Data Knowledge Service Platform, and Weipu Knowledge Resource System, and write and search "Theme $=$ Community Health Service Demand". In order to ensure the credibility and quality of the research literature, the source of the literature was limited to Chinese core journals and CSSCI searches. After excluding data that did not meet the research of this paper, 96 literatures were finally collected.

In this paper, the qualitative research software Nvivo11.0 is used to encode the collected documents in three-level coding through its powerful coding function.

\section{Qualitative Analysis}

Open coding is the process of identifying, decomposing, and conceptualizing the content of a document. In the process, the initial concept is obtained by narrowing the scope. This paper adheres to the concept of "continuous comparison" of grounded theory, summarized all services for community health service demands in local language, after several analyses, 103 initial concepts and 24 generics are obtained, as shown in "Table I":
TABLE I. INITIAL CONCEPTS AND GENERICS

\begin{tabular}{|c|c|c|}
\hline Generic & \multicolumn{2}{|c|}{ Conceptualization } \\
\hline $\begin{array}{l}\text { Community } \\
\text { Health Service } \\
\text { Publicity }\end{array}$ & $\begin{array}{l}\text { Lack of awareness of } \\
\text { community health services } \\
\text { Lack of trust in community } \\
\text { health care workers } \\
\text { Increase publicity on } \\
\text { community health services } \\
\text { Guide the demand for } \\
\text { community health services }\end{array}$ & \\
\hline $\begin{array}{l}\text { Medical Service } \\
\text { System }\end{array}$ & $\begin{array}{l}\text { Medical insurance system } \\
\text { Family doctor system } \\
\text { Two-way referral system } \\
\text { Service evaluation system }\end{array}$ & $\begin{array}{l}\text { Quality } \\
\text { management } \\
\text { system }\end{array}$ \\
\hline $\begin{array}{l}\text { Medical Service } \\
\text { Expense }\end{array}$ & $\begin{array}{l}\text { Develop a reasonable } \\
\text { service price } \\
\text { Improve payment method }\end{array}$ & \\
\hline $\begin{array}{l}\text { Financial } \\
\text { Investment of } \\
\text { Community } \\
\text { Health Service }\end{array}$ & $\begin{array}{l}\text { Fundraising and financial } \\
\text { compensation for } \\
\text { community health services } \\
\text { Include Community health } \\
\text { service institutions into } \\
\text { medical insurance } \\
\text { Special fund for medical } \\
\text { assistance }\end{array}$ & \\
\hline
\end{tabular}




\begin{tabular}{|c|c|c|}
\hline Generic & \multicolumn{2}{|c|}{ Conceptualization } \\
\hline $\begin{array}{lr}\text { Service } & \text { Agency } \\
\text { for } & \text { Policy } \\
\text { System } & \end{array}$ & 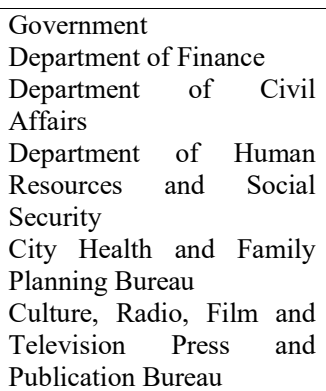 & $\begin{array}{l}\text { Community } \\
\text { committees } \\
\text { Community } \\
\text { volunteer group }\end{array}$ \\
\hline $\begin{array}{ll}\text { Basic } & \text { Medical } \\
\text { Service } & \end{array}$ & $\begin{array}{l}\text { Common disease diagnosis } \\
\text { and treatment } \\
\text { Emergency treatment } \\
\text { Regular medical } \\
\text { examination } \\
\text { Prescription } \\
\text { Intramuscular injection }\end{array}$ & $\begin{array}{l}\text { Intravenous } \\
\text { injection } \\
\text { Trauma treatment } \\
\text { Inpatient service } \\
\text { Floating } \\
\text { population } \\
\text { community health } \\
\text { service window }\end{array}$ \\
\hline $\begin{array}{l}\text { Family Medical } \\
\text { Service }\end{array}$ & $\begin{array}{l}\text { Family visit } \\
\text { Family care } \\
\text { Family bed }\end{array}$ & $\begin{array}{l}\text { Family doctor } \\
\text { Family nurse }\end{array}$ \\
\hline $\begin{array}{l}\text { Medical Referral } \\
\text { Service }\end{array}$ & $\begin{array}{l}\text { Green channel of medical } \\
\text { referral service } \\
\text { Follow-up visit for medical } \\
\text { referral service }\end{array}$ & \\
\hline $\begin{array}{ll}\text { Basic } & \text { Medical } \\
\text { Service } & \text { Support } \\
\text { Agency } & \end{array}$ & $\begin{array}{l}\text { General hospital } \\
\text { Specialist hospital } \\
\text { Technical steering group }\end{array}$ & \\
\hline Health Education & $\begin{array}{l}\text { prevention knowledge of } \\
\text { common disease } \\
\text { prevention knowledge of } \\
\text { infectious disease } \\
\text { prevention knowledge of } \\
\text { chronic disease } \\
\text { prevention knowledge of } \\
\text { cancer } \\
\text { Nutritional diet guidance } \\
\text { Lifestyle guidance }\end{array}$ & $\begin{array}{l}\text { Physical exercise } \\
\text { guidance } \\
\text { Medical guidance } \\
\text { Medication } \\
\text { guidance } \\
\text { Prenatal advisory } \\
\text { Health Advisory }\end{array}$ \\
\hline $\begin{array}{l}\text { Disease } \\
\text { Prevention and } \\
\text { Control }\end{array}$ & $\begin{array}{l}\text { Management of infectious } \\
\text { disease } \\
\text { Monitoring and treatment } \\
\text { of epidemiology, endemic } \\
\text { disease, occupational } \\
\text { disease } \\
\begin{array}{l}\text { Prevention of chronic } \\
\text { disease }\end{array}\end{array}$ & \\
\hline $\begin{array}{ll}\text { Mental } & \text { Health } \\
\text { Service } & \end{array}$ & $\begin{array}{l}\text { Psychiatric community } \\
\text { management } \\
\text { Mental health guidance } \\
\text { Psychological Counseling } \\
\text { Psychotherapy }\end{array}$ & \\
\hline $\begin{array}{l}\text { Health care } \\
\text { Service }\end{array}$ & $\begin{array}{l}\text { Children health care } \\
\text { Women health care } \\
\text { Elderly health care } \\
\text { Family health care }\end{array}$ & \\
\hline
\end{tabular}

\begin{tabular}{|c|c|c|}
\hline Generic & \multicolumn{2}{|c|}{ Conceptualization } \\
\hline $\begin{array}{l}\text { Rehabilitation } \\
\text { Service }\end{array}$ & $\begin{array}{l}\text { Disability rehabilitation } \\
\text { guidance } \\
\text { Rehabilitation training } \\
\text { Rehabilitation Center }\end{array}$ & \\
\hline $\begin{array}{l}\text { Family Planning } \\
\text { Technical } \\
\text { Service }\end{array}$ & $\begin{array}{l}\text { Family planning technical } \\
\text { guidance }\end{array}$ & \\
\hline $\begin{array}{l}\text { Chinese Medical } \\
\text { Service }\end{array}$ & $\begin{array}{l}\text { Cupping } \\
\text { Massage } \\
\text { Acupuncture } \\
\text { Chinese patent medicine }\end{array}$ & $\begin{array}{l}\text { Chinese medicine } \\
\text { science } \\
\text { knowledge } \\
\text { Traditional } \\
\text { Chinese Medicine } \\
\text { Service Area }\end{array}$ \\
\hline $\begin{array}{l}\text { Professional } \\
\text { Public Health } \\
\text { Agency }\end{array}$ & $\begin{array}{l}\text { Centers for Disease } \\
\text { Control and Prevention } \\
\text { Maternal and Child Health } \\
\text { Hospital } \\
\text { Health education institute } \\
\text { Specialist hospital }\end{array}$ & \\
\hline $\begin{array}{l}\text { Geriatric care } \\
\text { services }\end{array}$ & $\begin{array}{l}\text { Geriatrics } \\
\text { Aged care unit } \\
\text { Hospice care bed } \\
\text { Geriatric rehabilitation } \\
\text { guidance } \\
\begin{array}{l}\text { Elderly mental health } \\
\text { education }\end{array}\end{array}$ & \\
\hline $\begin{array}{l}\text { Elderly } \quad \text { care } \\
\text { service }\end{array}$ & $\begin{array}{l}\text { Elderly activity center } \\
\text { Elderly lifestyle guidance } \\
\text { Elderly diet nutrition } \\
\text { guidance }\end{array}$ & $\begin{array}{l}\text { Home care service } \\
\text { Elderly nursing } \\
\text { service }\end{array}$ \\
\hline $\begin{array}{l}\text { Medical } \\
\text { Expenses }\end{array}$ & $\begin{array}{l}\text { No obvious price } \\
\text { advantage } \\
\text { Medical expense is too } \\
\text { high } \\
\text { Reimbursement delay for } \\
\text { medical expense }\end{array}$ & $\begin{array}{l}\text { Medical expenses } \\
\text { are not reimbursed } \\
\text { for default } \\
\text { Medical expenses } \\
\text { cannot be } \\
\text { reimbursed }\end{array}$ \\
\hline Service problem & $\begin{array}{l}\text { Service is not timely } \\
\text { Poor service attitude } \\
\text { Less service project }\end{array}$ & \\
\hline $\begin{array}{l}\text { Human Resource } \\
\text { problem }\end{array}$ & $\begin{array}{l}\text { Low technical level of } \\
\text { medical staff } \\
\text { Low quality of medical } \\
\text { staff } \\
\text { Low qualification for } \\
\text { medical staff }\end{array}$ & \\
\hline $\begin{array}{l}\text { Equipment } \\
\text { problem }\end{array}$ & $\begin{array}{l}\text { Poor medical environment } \\
\text { Incomplete medicine } \\
\text { Unimproved medical } \\
\text { equipment } \\
\text { old and poor medical } \\
\text { equipment }\end{array}$ & \\
\hline $\begin{array}{l}\text { Complaint and } \\
\text { recommendation } \\
\text { agency }\end{array}$ & Health Supervision Offices & \\
\hline
\end{tabular}

Main axial coding is to classify the relationship between various generics by continually comparing and analyzing the concept generics to form the main generics. By encoding the 24 generic formed in the open coding, 10 main generics are formed, as shown in "Table II". 
TABLE II. GENERIC, MAIN GENERIC AND RELATIONSHIP CONNOTATION

\begin{tabular}{|c|c|c|}
\hline $\begin{array}{c}\text { Main } \\
\text { Generic }\end{array}$ & Generic & $\begin{array}{l}\text { Relationship } \\
\text { Connotation }\end{array}$ \\
\hline $\begin{array}{l}\text { Policy } \\
\text { system } \\
\text { service } \\
\text { demand }\end{array}$ & $\begin{array}{l}\text { Community health service } \\
\text { publicity } \\
\text { Medical service system } \\
\text { Medical service expense } \\
\text { Financial investment of } \\
\text { community health service }\end{array}$ & $\begin{array}{l}\text { Belong to the } \\
\text { demands of policy } \\
\text { system related to } \\
\text { community health } \\
\text { service }\end{array}$ \\
\hline $\begin{array}{l}\text { Policy } \\
\text { system } \\
\text { service } \\
\text { agency }\end{array}$ & Policy system service agency & $\begin{array}{lr}\text { agencies } & \text { provide } \\
\text { service for } & \text { relative } \\
\text { policies } & \text { of } \\
\text { community } & \text { health } \\
\text { service } & \\
\end{array}$ \\
\hline $\begin{array}{l}\text { Basic } \\
\text { medical } \\
\text { service } \\
\text { demand }\end{array}$ & $\begin{array}{l}\text { Basic medical service } \\
\text { Family medical service } \\
\text { Referral service }\end{array}$ & $\begin{array}{l}\text { Basic medical service } \\
\text { should be provided } \\
\text { by community health } \\
\text { service agency }\end{array}$ \\
\hline $\begin{array}{l}\text { Basic } \\
\text { medical } \\
\text { service } \\
\text { support } \\
\text { agency }\end{array}$ & $\begin{array}{l}\text { Basic medical service support } \\
\text { agency }\end{array}$ & $\begin{array}{l}\text { Agency that assists } \\
\text { community health } \\
\text { service providing } \\
\text { basic medical } \\
\text { services to residents }\end{array}$ \\
\hline $\begin{array}{l}\text { Public } \\
\text { health } \\
\text { service } \\
\text { demand }\end{array}$ & $\begin{array}{l}\text { Health education } \\
\text { Disease prevention and control } \\
\text { Mental health service } \\
\text { Health care service } \\
\text { Rehabilitation service } \\
\text { Family planning technical } \\
\text { service } \\
\text { Chinese medicine service }\end{array}$ & $\begin{array}{l}\text { Public health services } \\
\text { required by } \\
\text { community health } \\
\text { services }\end{array}$ \\
\hline $\begin{array}{l}\text { Public } \\
\text { health } \\
\text { service } \\
\text { agency }\end{array}$ & $\begin{array}{l}\text { Professional public health } \\
\text { agency }\end{array}$ & $\begin{array}{l}\text { Agency that assists } \\
\text { community health } \\
\text { service providing } \\
\text { basic medical } \\
\text { services to residents }\end{array}$ \\
\hline $\begin{array}{l}\text { Elderly } \\
\text { medical } \\
\text { service } \\
\text { demand }\end{array}$ & Elderly medical service & $\begin{array}{l}\text { Demands of } \\
\text { community elderly } \\
\text { for medical services }\end{array}$ \\
\hline $\begin{array}{l}\text { Elderly } \\
\text { nursing } \\
\text { demand }\end{array}$ & Elderly nursing service & $\begin{array}{lr}\text { Demands } & \text { of } \\
\text { community } & \text { elderly } \\
\text { for elderly } & \text { nursing } \\
\text { service } & \\
\end{array}$ \\
\hline $\begin{array}{l}\text { Complaint } \\
\text { recommen } \\
\text { dation } \\
\text { demand }\end{array}$ & $\begin{array}{l}\text { Medical expense problem } \\
\text { Service problem } \\
\text { Human resource problem } \\
\text { Equipment problem }\end{array}$ & $\begin{array}{l}\text { Residents have } \\
\text { encountered many } \\
\text { problems in the use } \\
\text { of community health } \\
\text { services, and urgently } \\
\text { need feedback. }\end{array}$ \\
\hline $\begin{array}{l}\text { Complaint } \\
\text { recommen } \\
\text { dation } \\
\text { agency }\end{array}$ & Health Supervision Offices & $\begin{array}{l}\text { agency to receive the } \\
\text { feedback of residents }\end{array}$ \\
\hline
\end{tabular}

Selective coding is a re-enhancement of the concept. By analyzing the system of the main generic, the "core genus" is selected to construct a new theoretical model. Through the analysis and integration of the main generic genus, this article codes the "policy system service demand" and "policy system service organization" as the core generic "policy system service"; code the "basic medical service demand" and "basic medical service support institution" as the core generic of "basic medical services"; cede the "public health service demand" and "public health service agency" as the core generic of "public health service"; code the "elderly medical care service demand" and "elderly nursing service" as the core generic of "elderly service"; code the "complaint recommendation requirement" and "complaint recommendation agency" as the core generic of "complaint recommendation service", and the above five core generics together formed the whole content of community health service (see "Fig. 2").

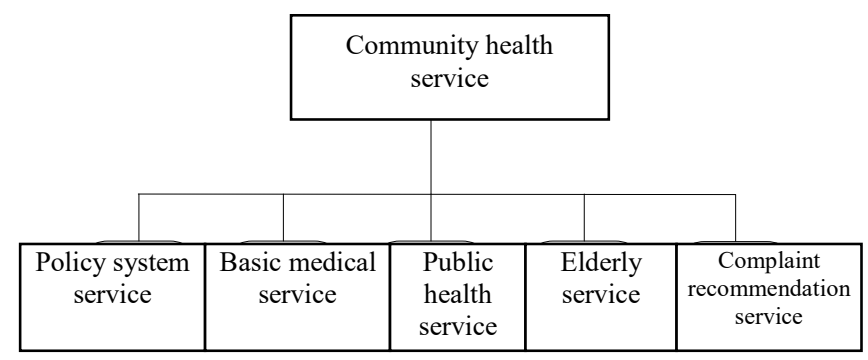

Fig. 2. Selective coding of community health services.

\section{Urban Community Health Service Chain Model CONSTRUCTION}

According to the theoretical model of service chain and urban community health service demand analysis, this paper constructs the urban community health service chain framework, as shown in "Fig. 3". The framework is based on government departments, health institutions and various social organizations as the objective to provide policy system services, basic medical services, public health services, services for the elderly, and complaints and suggestions services to community residents, so that to form the entire service system of the service chain. 


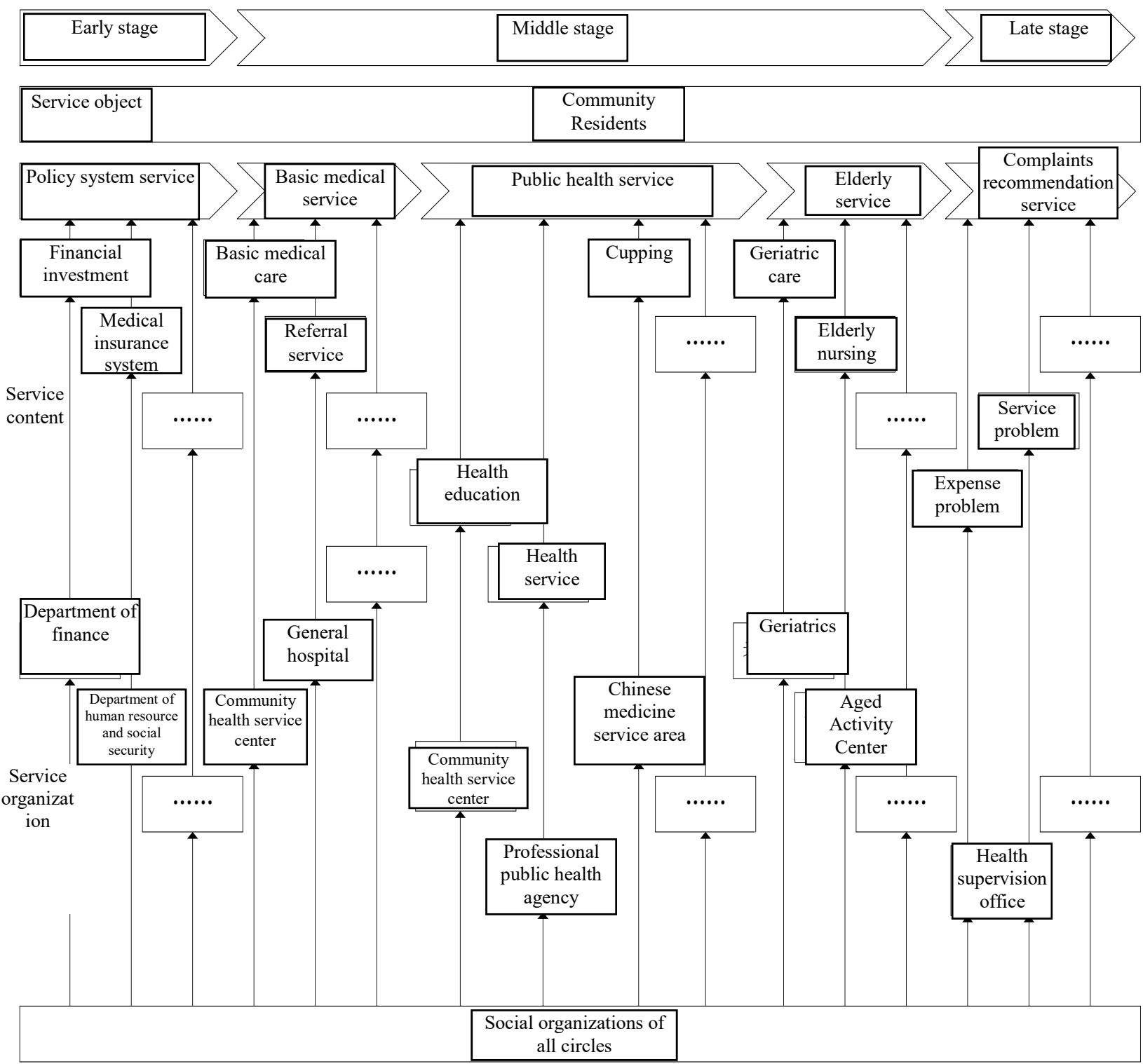

Fig. 3. Urban community health service chain model.

The various "nodes" in the framework of the urban community health service chain include:

(1) Policy system service chain "node": government guide the policy system service for urban community health services; Department of Finance and Department of Civil Affairs provide financial input for urban community health services, such as economic compensation, special funds for medical assistance, etc.; And the Department of Human Resource and Social Security formulate and improve the medical service system, such as the medical insurance system and the family doctor system; Municipal Health and Family Planning Bureau formulate and improve the quality management system and service evaluation system for urban community health services; community neighborhood committees and community volunteer groups cooperate with government departments to carry out publicity activities on urban community health services.

(2) Basic medical service chain "node": Community health service center (station) provide basic medical services for community residents, such as common disease diagnosis and treatment, emergency diagnosis and treatment, etc.; general hospitals, specialist hospitals, etc. cooperate with community health service centers (station) to provide referral services for residents, etc.

(3) Public health service chain "node": Community health service center (station) provide public health services for residents, such as health education, disease prevention and control, mental health services, health services, rehabilitation services, family planning technical services, medical services, etc.; professional public health agencies cooperate with 
community health service centers (stations) to provide public health services to residents.

(4) Elderly service "node": geriatrics, aged care unit and hospice care beds, etc., provide medical services for the elderly; other institutions such as the Aged Activity Center provide home-based care services and elderly nursing services.

(5) Complaints recommendation service chain "nodes": Health Supervision Offices receive problems such as medical expenses and service problems encountered by residents in the process of using urban community health services.

\section{CONCLUSION}

This paper only analyzes the service content and service organization of the community health service chain, but did not make further consideration on how the community health service chain plays a role in the actual operation. In the subsequent research, a certain area can be selected as the research object to improve the service chain model through exploration and research.

\section{REFERENCES}

[1] National Health and Family Planning Commission Office. "Implementation Plan of Community Health Service Improvement Project" [Z].2015-11-20 (in Chinese)

[2] Liu Hongyu, Song Miao, Li Lingui, et al. "Analysis of the demands of community health service agencies based on the World Health Organization WISN method" [J]. China Health Economics, 2017, 36 (01): 53-56. (in Chinese)

[3] Yang Xuesong, Wang Fuhua, Yang Wei, et al. "Demand analysis of infectious disease knowledge training in community health service institutions in the 8th district of Beijing" [J]. China Health Care Management, 2011, 28(10): 797-799. (in Chinese)

[4] Zheng Chanjiao, Shi Mingli, Shen Huanyu, et al. "Analysis of current status and demands of health service personnel training ability in community health service centers in Guangdong Province" [J]. Chinese General Practice, 2015 (19): 2320-2324. (in Chinese)

[5] Wang Haiyin, Jin Chunlin, Zhang Tianye. "Investigation on the Health Appropriate Technology Cognition and Demands of Clinical Medical Staff in Shanghai Community Health Service Center'[J].Chinese Medical, 2013, 16(28):3382-3384. (in Chinese)

[6] Zhang Jianfeng, Li Zhiju, WangG Fangyun, et al. "Research on community health service demand and influencing factors of community empty nest in Hefei City"'J]. Journal of Nursing Research, 2010, 24(7): 647-650. (in Chinese)

[7] Chen Ying. "Diversified demands of the elderly and the construction of community medical service system"[J]. Chinese Gerontology, 2016, 36(17): 4399-4401. (in Chinese)

[8] Ma Guofang, Liang Zuyue, He Guixiang, et al. "Investigation and analysis of the demand and utilization of community health services for floating population in Urumqi'[J]. Medicine and Philosophy, 2017, 38(7): 51-55. (in Chinese)

[9] Qi Jia,Wang Haiyan,Zong Gang. "Research on Service Chain Theory"[J].Journal of Beijing Polytechnic University(Social Science Edition), 2006, 6(4):22-25. (in Chinese) 